\title{
Toxic activity of Prunus spinosa L. flower extract in hepatocarcinoma cells
}

\author{
Teuta Murati ${ }^{1}$, Marina Miletić ${ }^{1}$, Josipa Kolarić1 ${ }^{1}$ Vanja Lovrić ${ }^{2}$ Danijela Bursać Kovačević \\ Predrag Putnik ${ }^{2}$, Irena Landeka Jurčević ${ }^{3}$, Domagoj Đikić ${ }^{4}$, Verica Dragović-Uzelac ${ }^{2}$, and \\ Ivana Kmetič ${ }^{1}$ \\ ${ }^{1}$ Laboratory for Toxicology, Faculty of Food Technology and Biotechnology, University of Zagreb, Zagreb, Croatia \\ ${ }^{2}$ Laboratory for Technology of Fruits and Vegetables Preservation and Processing, Faculty of Food Technology and \\ Biotechnology, University of Zagreb, Zagreb, Croatia \\ ${ }^{3}$ Laboratory for Food Chemistry and Biochemistry, Faculty of Food Technology and Biotechnology, University of \\ Zagreb, Zagreb, Croatia \\ ${ }^{4}$ Division of Animal Physiology, Faculty of Science, University of Zagreb, Zagreb, Croatia
}

[Received in July 2019; Similarity Check in July 2019; Accepted in November 2019]

Prunus spinosa L. (blackthorn) is used in traditional medicine as a remedy for various diseases. To establish its anticancer properties, we exposed human liver cancer cells (Hep G2) to a range of blackthorn flower extract concentrations (10-200 $\mu \mathrm{g} / \mathrm{mL})$ and determined cytotoxic activity with the neutral red and kenacid blue methods after 24,48 , and $72 \mathrm{~h}$ of incubation. Statistically significant inhibitory effects on Hep G2 cellular proliferation were observed at concentrations above $50 \mu \mathrm{g} / \mathrm{mL}(\mathrm{p}<0.001-0.05)$. Cell viability was lower when determined with neutral red than kenacid blue method. In addition, we evaluated antioxidant/ prooxidant effects of the blackthorn flower extract by measuring reactive oxygen species (ROS), and the results confirmed its prooxidant behaviour within the applied concentration range. Flow cytometry determined primarily necrotic and apoptotic cell death, which provides additional evidence of its cytotoxic effect on liver carcinoma.

KEY WORDS: blackthorn; cytotoxicity; Hep G2; kenacid blue; neutral red; ROS

Croatian folk and official medicine and pharmacy lists 735 plant species used as a remedy for various diseases (1), including Prunus spinosa L. (blackthorn). Its petals are used medicinally as tea, syrup, fresh juice, or tincture to treat diarrhoea, anaemia, and other ailments (2). Its flower is a valuable source of phenolic compounds, such as kaempferol, quercetin, kaempferol 3-O- $\alpha$-L-arabinofuranoside, quercetin 3-O- $\alpha$-L-arabinofuranoside, kaempferol 3-O- $\alpha$ L-ramnopyranoside, kaempferol 7-O- $\alpha$-L-ramnopyranoside, kaempferol 3-O- $\beta$-D-xylopyranoside, and kaempferol 3-O-(2"'-E- $p$-coumaroyl)- $\alpha$-L-arabinofuranoside $(3,4)$. These polyphenols have potent antioxidant/prooxidant properties and a potential to treat cancer either as prophylaxis (antioxidants) or cancer cell killers (prooxidants) $(5,6)$.

Liver cancer is the third most common cause of death from cancer worldwide, with overall mortality-to-incidence rate of 0.93 (7). The incidence of primary liver malignancy has increased over the past 20 years, with hepatocellular carcinoma being the most common primary liver tumour (8). This is one of the reasons why current research has been focused on identifying chemotherapeutic agents that

Corresponding author: Professor Ivana Kmetič, $\mathrm{PhD}$, Laboratory for Toxicology, Faculty of Food Technology and Biotechnology, University of Zagreb, 10000 Zagreb, Pierottijeva 6, Croatia, E-mail: ikmetic@pbf.hr can prevent, delay, or stop tumour initiation and growth and reduce mortality.

Cytotoxicity screening models provide important preliminary data to help identify plant extracts with potential anticancer activity for future study $(9,10)$. The aim of this in vitro study was to assess the anticancer properties of Prunus spinosa L. flower ethanolic extract (PSBE) in human hepatoblastoma cells (Hep G2) and is an update to our recently published report on blackthorn flower extract activity at the cellular level (11).

\section{MATERIALS AND METHODS}

Reagents, solvents, and standards

Dulbecco's Modified Eagle's Medium Nutrient Mixture F-12 Ham (DMEM/F12), trypsin/EDTA solution (0.25\% trypsin with EDTA $4 \mathrm{Na})$, trypan blue dye, 3-(4,5-dimethylthiazol-2-yl)-2,5-diphenyltetrazolium bromide (MTT), and gallic acid were purchased from Sigma-Aldrich Chemical Co. (St. Louis, MO, USA). Heatinactivated foetal bovine serum (FBS) was obtained from GIBCO (Paisley, UK). Coomassie brilliant blue R-250 was obtained from LKB (Bromma, Sweden), and neutral red dye from Merck (Darmstadt, Germany). 
2',7'-dichlorodihydrofluorescein diacetate (DCFDA) assay kit (cat \#ab113851) was obtained from Abcam (Cambridge, UK) and Muse Annexin V \& Dead Cell Kit (cat \#MCH100105) from Merck Millipore (Billerica, MA, USA). Ethanol was purchased from Gram-Mol (Zagreb, Croatia). Folin-Ciocalteu reagent was obtained from Kemika (Zagreb, Croatia), and anhydrous sodium carbonate from T.T.T. (Sveta Nedjelja, Croatia).

\section{Plant material}

Dried flowers of wild blackthorn (Prunus spinosa L.) were obtained from a local producer (Suban Ltd., Strmec, Croatia). Before analyses, the flowers were ground to powder with an electrical grinder $(150 \mathrm{~W}$, Imetec Dolcevita CG1, Azzano San Paolo, Italy) and the process was stopped every $15 \mathrm{~s}$ for $10 \mathrm{~s}$ to prevent sample from heating. Particle size and the powder distribution were $\mathrm{d}(0.9) \leq 405.24 \mu \mathrm{m}$; $\mathrm{d}(0.5) \leq 180.90 \mu \mathrm{m} ; \mathrm{d}(0.1) \leq 16.26 \mu \mathrm{m}$, as determined with a laser particle size analyser (MASTERSIZER 2000, Malvern Instruments, Worcestershire, UK).

\section{Extraction procedure}

Phenolic compounds were extracted following a procedure described in detail in our previous paper (11), which was a modification of a procedure described by Bursać Kovačević et al. (12).

\section{Determination of total polyphenols}

Total phenols in the extract were determined following previously reported methods $(13,14)$. Briefly, $100 \mu \mathrm{L}$ of (300 times) diluted wild blackthorn extract was mixed with $200 \mu \mathrm{L}$ of Folin-Ciocalteu reagent and $2 \mathrm{~mL}$ of distilled water, and $1 \mathrm{~mL}$ of saturated $(20 \%, \mathrm{w} / \mathrm{v})$ sodium carbonate solution was added after $3 \mathrm{~min}$. The mixture was incubated at $50{ }^{\circ} \mathrm{C}$ for $30 \mathrm{~min}$, and the absorbance was measured with a UV-1600 PC spectrophotometer (Geldenaaksebaan, Leuven) at $765 \mathrm{~nm}$. Total phenolic content was calculated according to the gallic acid standard calibration curve $\left(y=0.0035 x, R^{2}=0.9995\right)$ and was $21.5 \mathrm{mg}$ of gallic acid equivalents (GAE) per gram of wild blackthorn flowers.

\section{Cell viability analysis}

Human Caucasian hepatocyte carcinoma cells Hep G2 (HB-8065, American Type Culture Collection, Manassas, VA, USA) were grown in DMEM/F12 supplemented with $10 \% \mathrm{FBS}$ at $37^{\circ} \mathrm{C}$ in a $5 \% \mathrm{CO}_{2}$ humidified environment. Antibiotics were not used. To evaluate the cytotoxicity of PSBE, Hep G2 cells were trypsinised and seeded into a 6 -well plates at a density of $5 \times 10^{4}$ cells $/ \mathrm{mL}(2 \mathrm{~mL}$ per well $)$ and allowed to attach for $24 \mathrm{~h}$. The cells were then treated in culture medium with $10 \mu \mathrm{L}$ of PSBE to obtain the desired total phenol concentration of $10-200 \mu \mathrm{g} / \mathrm{mL}$ expressed as GAE. The final ethanol concentration in the experiments was never greater than $0.5 \%$. Cytotoxic effects were evaluated after 24,48 , and $72 \mathrm{~h}$ of treatment. Cells treated with ethanol $(5 \mu \mathrm{L} / \mathrm{mL})$ were used as controls. Cytotoxicity was assessed using two different well-established in vitro test methods - kenacid blue assay and neutral red $(15,16)$ - with minor modifications as described earlier (17). The MTT test is often used to evaluate the anticancer activity of natural or synthesised compounds, but considering literature data (and ours as well), we have found it inappropriate for plant polyphenolic compounds (18). Polyphenols $\alpha-\beta-\gamma$ - $\delta$-tocotrienol and $\alpha$-tocopherol that are extracted from natural sources directly reduce MTT in the absence of living cells $(19,20)$. Bioassays that we have selected are based on the following principles: neutral red evaluates the ability of viable uninjured cells to incorporate and bind supravital dye in the lysosomes, and kenacid blue measures changes in total cell protein content. For each method at least three experiments were performed and each applied PSBE concentration was tested in triplicate within single experiment.

\section{Reactive oxygen species determination}

Cellular ROS was measured with a DCFDA assay kit according to manufacturer's protocol. After diffusion in a cell, a stable, fluorogenic dye DCFDA is deacetylated by cellular esterases to a non-fluorescent compound that is later oxidised by ROS into fluorescent 2, 7'dichlorofluorescein (21). Hep G2 cells were seeded into a 96-well black plates at a density of $2.5 \times 10^{5}$ cells $/ \mathrm{mL}$ (100 $\mu \mathrm{L}$ per well) and allowed to attach for $24 \mathrm{~h}$. The cells were then washed with PBS and incubated with $25 \mu \mathrm{mol} / \mathrm{L}$ DCFDA $(100 \mu \mathrm{L})$ at $37^{\circ} \mathrm{C}$ for $45 \mathrm{~min}$. After washing with PBS, they were exposed to PSBE $(10,50,100,150$, and $200 \mu \mathrm{g} / \mathrm{mL}$ ) for $3 \mathrm{~h}$. Fluorescence was measured with Cary Eclipse fluorescence spectrophotometer (Varian, Palo Alto, CA, USA) at $485 \mathrm{~nm}$ excitation and $535 \mathrm{~nm}$ emission wavelengths. All concentrations were tested in quadruplicate.

\section{Apoptosis assay}

After $48 \mathrm{~h}$ of treatment with 10,50 , and $100 \mu \mathrm{g} / \mathrm{mL}$ PSBE, floating and adherent Hep G2 cells (cultured in 6 -well plates at a density of $5 \times 10^{4}$ cells $/ \mathrm{mL} ; 2 \mathrm{~mL}$ per well) were collected, centrifuged at $600 \mathrm{~g}$ for $1 \mathrm{~min}$, and suspended in cell culture medium. Then, $100 \mu \mathrm{L}$ aliquots of cell suspension were added to $100 \mu \mathrm{L}$ of Muse Annexin $\mathrm{V} \&$ Dead Cell reagent, incubated in the dark at room temperature for $20 \mathrm{~min}$, and analysed with a Muse Cell Analyzer (Merck Millipore). Each PSBE concentration was tested in quadruplicate. Cytofluorimetric separation, based on externalisation of phosphatidylserine (positivity for annexin V) in apoptotic cells and simultaneous staining of dead cells with fluorescent nuclear dye 7-aminoactinomycin $\mathrm{D}$ (7-AAD) distinguished four cell populations in each sample: non-apoptotic live (Annexin V-negative and 7-AAD-negative), early apoptotic (Annexin V-positive and 7-AAD-negative), late-stage apoptotic and dead cells 
(Annexin V-positive and 7-AAD-positive), and dead cells, mostly nuclear debris (Annexin V-negative and 7-AADpositive) (22).

\section{Statistical analysis}

All data are presented as means \pm SEM. The results were analysed with a two-tailed Student's $t$-test, and $p<0.05$ was considered statistically significant.

\section{RESULTS AND DISCUSSION}

\section{Cytotoxic effects of PSBE}

The first significant cytotoxic events were detected with both neutral red and kenacid blue $(p<0.001$ and $p<0.05$, respectively) after $24 \mathrm{~h}$ of exposure to $50 \mu \mathrm{g} / \mathrm{mL}$ of PSBE and both methods confirmed that cytotoxicity was dosedependent (Figure 1 and 2). However, the comparison between $\mathrm{IC}_{50}$ revealed differences between the methods (Table 1), as those obtained with kenacid blue were higher than those obtained with neutral red, which points to higher sensitivity of the latter. After $72 \mathrm{~h}$ of exposure to $200 \mu \mathrm{g} / \mathrm{mL}$ of PSBE, neutral red showed that almost none of the cells survived. These findings indicate that blackthorn flower polyphenols might affect lysosomes/endosomes in Hep G2 cells. However, at its lowest concentration PSBE had a positive effect on cell proliferation (although it was not statistically significant), which points future research in the direction of possible PSBE protective effects in normal cells and tissues at doses below $10 \mu \mathrm{g} / \mathrm{mL}$.

\section{Prooxidative effects of PSBE}

PSBE significantly increased ROS production (Figure 3 ) at all tested concentrations in a dose-dependent manner. This effect is welcome in liver cancer cells. Targeting cancer cells via ROS-based mechanism has been proposed as a relatively novel, radical therapeutic approach. Cancer cells exhibit higher endogenous oxidative stress than normal cells, and pharmacological ROS insults through either greater ROS production or inhibition of ROS-scavenging activity can lead to increased (lethal) ROS levels in them $(23,24)$. Other studies also reported that polyphenol-rich plant extracts and pure polyphenol compounds could behave as prooxidants under certain conditions $(5,6,25)$. Prooxidant molecules can act as cytotoxic agents against cancer cells by achieving toxic ROS levels associated with their apoptotic effect in various types of tumour cells (26).

\section{Cell death induced by PSBE}

Cytofluorimetric analysis of apoptotic events showed that $48 \mathrm{~h}$ of treatment with PSBE significantly increased $(p<0.001)$ the percentage of total apoptotic cells compared to control (Figure 4). Interestingly, the lowest applied dose of PSBE $(10 \mu \mathrm{g} / \mathrm{mL})$ resulted in the highest percentage of early apoptotic cells, even though neutral red and kenacid blue did not detect cytotoxic effects at this dose. At higher PSBE doses (50 and $100 \mu \mathrm{g} / \mathrm{mL}$ ) the percentage of early apoptotic cells decreased, and the majority of cells were late apoptotic or dead. Flavonoids are known to interact with the pathways signalling cell growth and apoptosis such as PI3-kinase (phosphoinositide 3-kinase), Akt/Pkb (protein-kinase B), tyrosine-kinase, $\mathrm{P} 1 \mathrm{KC}$ (protein-1 kinase

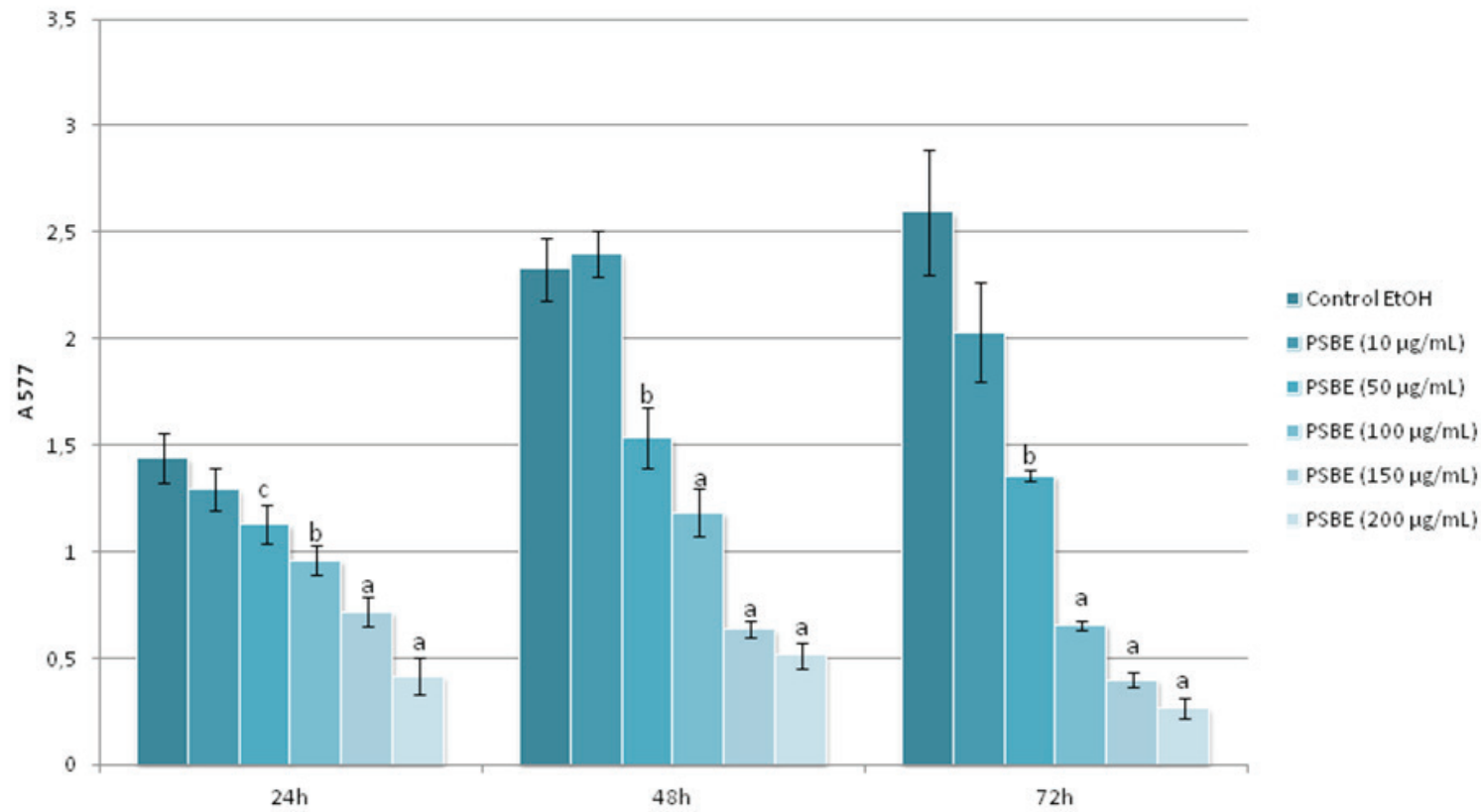

Figure 1 Effects of blackthorn flower extract on Hep G2 cell viability (mean \pm SEM) determined with kenacid blue after 24, 48, and $72 \mathrm{~h} ;{ }^{\mathrm{a}} \mathrm{p}<0.001 ;{ }^{\mathrm{b}} \mathrm{p}<0.005 ;{ }^{\mathrm{c}} \mathrm{p}<0.05$ (vs control). Control EtOH - cells treated with $5 \mu \mathrm{L} / \mathrm{mL}$ ethanol; PSBE $10,50,100,150$, and $200 \mu \mathrm{g} / \mathrm{mL}$ - concentrations of PSBE in growth medium 
Table 1 Inhibition concentrations of Prunus spinosa L. flower extract in Hep G2 cells after 24, 48, and 72 h

\begin{tabular}{|c|c|c|c|c|c|c|}
\hline \multirow{3}{*}{$\begin{array}{l}\text { IC } \mu \mathrm{g} / \mathrm{mL} \\
\text { Method }\end{array}$} & \multicolumn{6}{|c|}{ Time } \\
\hline & \multicolumn{2}{|c|}{$24 \mathrm{~h}$} & \multicolumn{2}{|c|}{$48 \mathrm{~h}$} & \multicolumn{2}{|c|}{$72 \mathrm{~h}$} \\
\hline & KB & NR & KB & NR & KB & NR \\
\hline $\mathrm{IC}_{20}$ & 64.59 & 37.81 & 36.30 & 19.49 & 20.49 & 24.76 \\
\hline $\mathrm{IC}_{50}$ & 148.11 & 92.50 & 94.49 & 63.28 & 59.87 & 54.93 \\
\hline $\mathrm{IC}_{80}$ & 212.90 & 163.42 & 1 & 127.17 & 121.07 & 95.98 \\
\hline
\end{tabular}

$\mathrm{KB}-$ kenacid blue; NR - neutral red

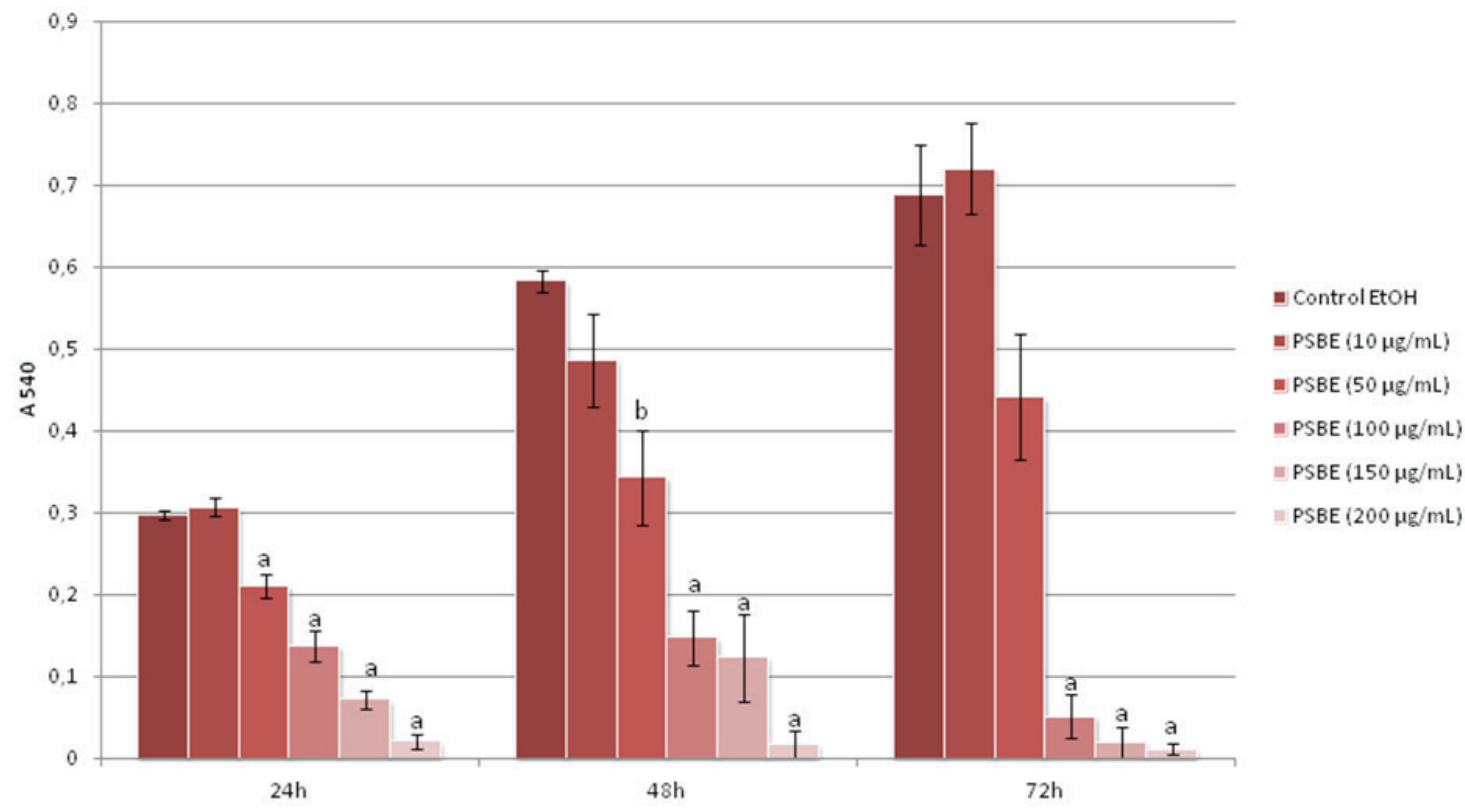

Figure 2 Effects of blackthorn flower extract on Hep G2 cell viability (mean \pm SEM) determined with neutral red after 24, 48, and 72 h; ${ }^{\mathrm{a}} \mathrm{p}<0.001 ;{ }^{\mathrm{b}} \mathrm{p}<0.01$ (vs control). Control EtOH - cells treated with $5 \mu \mathrm{L} / \mathrm{mL}$ ethanol; PSBE 10, 50, 100, 150, and $200 \mu \mathrm{g} / \mathrm{mL}-$ concentrations of PSBE in growth medium

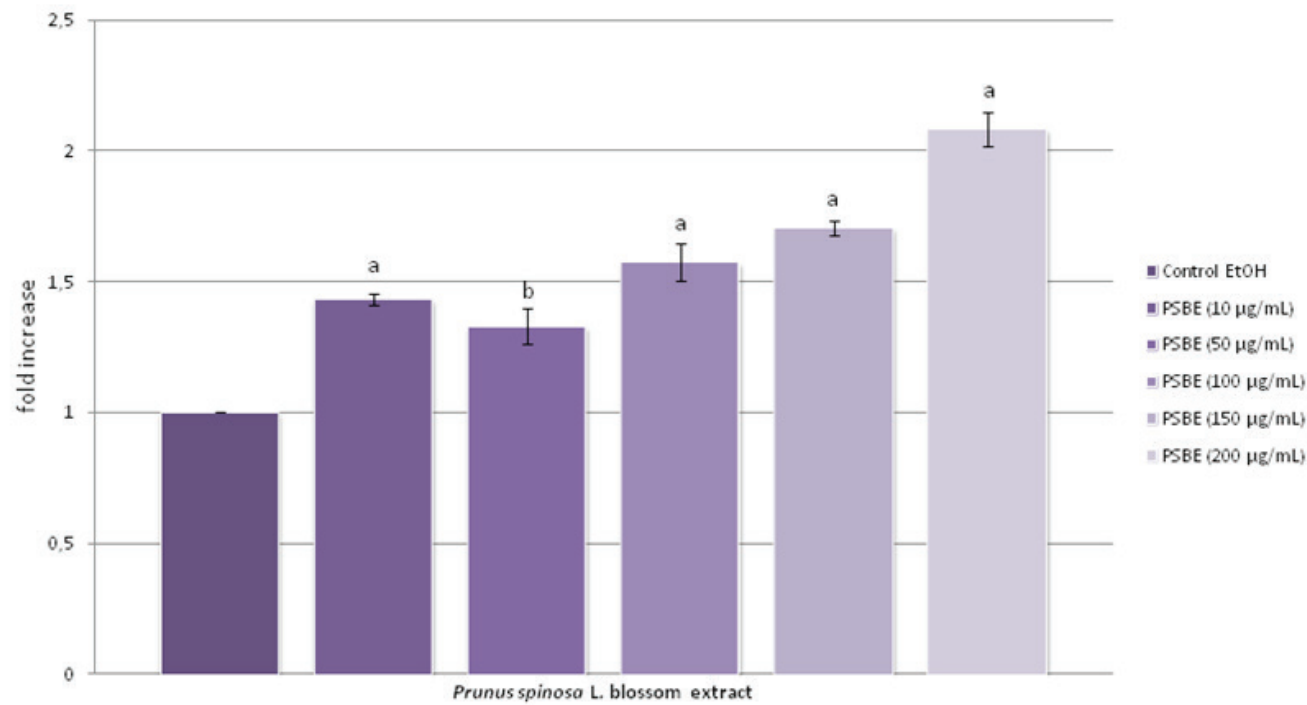

Figure 3 Mean $\left( \pm\right.$ SEM) increase in ROS generation in Hep G2 cells by blackthorn flower extract; ${ }^{\mathrm{a}} \mathrm{p}<0.001 ;{ }^{\mathrm{b}} \mathrm{p}<0.01$ (vs control). Control EtOH - cells treated with $5 \mu \mathrm{L} / \mathrm{mL}$ ethanol; PSBE 10, 50, 100, 150, and $200 \mu \mathrm{g} / \mathrm{mL}$ - concentrations of PSBE in growth medium 
A
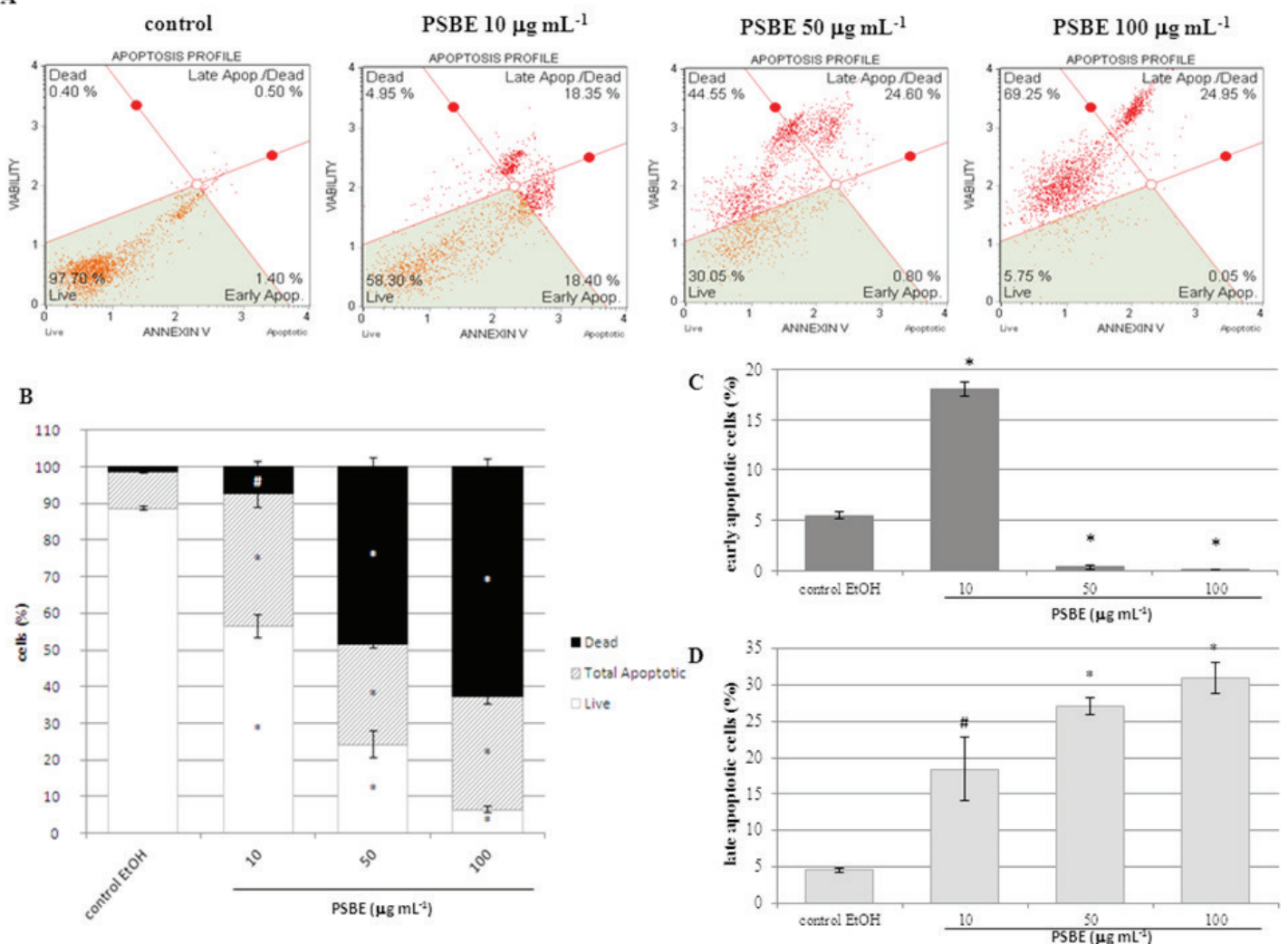

Figure 4 Cell death by apoptosis in Hep G2 cells treated with blackthorn flower extract (PSBE) at concentrations of 10, 50, and $100 \mu \mathrm{g} / \mathrm{mL}$ for $48 \mathrm{~h}$. (A) Representative dot plot profiles of untreated and PSBE-treated cells; (B) Distribution of live, total apoptotic, and dead cells (mean $\pm \mathrm{SEM}$ ); (C) Distribution of early apoptotic cells relative to the total number of cells (mean $\pm \mathrm{SEM}$ ); (D) Distribution of late apoptotic/ dead cells relative to the total number of cells (mean $\pm \mathrm{SEM}$ ); ${ }^{*} \mathrm{p}<0.001, \# \mathrm{p}<0.025$ vs. the respective controls

C), and MAP (mitogen-activated protein)-kinase. They can also alter growth signalling by inhibiting receptor phosphorylation or by arresting growth factors binding to receptors. Quercetin, for example, can induce thymidylate synthase-mediated apoptosis at high concentrations (27). Quercetin and kaempferol have already been detected and quantified in Prunus spinosa L. flower extract $(3,4)$, and our results seem to implicate their apoptotic signalling role in addition to prooxidative cytotoxic action. Most of the necrotic cells in our study can be explained with high cyanogenic glucoside content in the genus Prunus, as reported earlier (11).

\section{CONCLUSION}

Our study confirms that blackthorn flower extract in the concentration range of $50-200 \mu \mathrm{g} / \mathrm{mL}$ is toxic to human liver cancer cells and induces apoptotic/necrotic cell death, most likely through increased oxidative stress (ROS production). Previously, we have demonstrated similar effects in mouse hepatocarcinoma cells (Hepa 1-6) but also pointed out toxic effects in non-neoplastic, normal hepatocytes (AML-12) (11). Further studies are required in order to evaluate the in vivo anticancer efficacy of PSBE and selectivity regarding normal cells and tissues. Doses of PSBE below $10 \mu \mathrm{g} / \mathrm{mL}$ should be investigated for antioxidative and protective effects at the cellular level. Additionally, a promising area of research is combining phytomedicine or natural products with synthetic drugs or introducing these into conventional treatment regimens. Combination of natural and synthetic drugs proved to be an alternative strategy to generate synergistic anticancer effects, reduce toxicity associated with individual drug, suppress resistance associated with multiple drugs, and enhance the treatment effect $(28,29)$. Research of PSBE should also go in this direction.

\section{Acknowledgments}

This study was supported by the Croatian Science Foundation project no. 3035 "Application of innovative technologies for production of plant extracts as ingredients for functional food (IT-PE-FF)".

\section{Conflicts of interest}

None to declare. 


\section{REFERENCES}

1. Nikolić T, Rešetnik I. Plant uses in Croatia. Phytol Balcan 2007;13:229-38.

2. Popescu I, Caudullo G. Prunus spinosa in Europe: distribution, habitat, usage and threats. In: San-Miguel-Ayanz J, de Rigo D, Caudullo G, Durrant TH, Mauri A, editors. European atlas of forest tree species. Luxembourg: Publication Office of the European Union; 2016, p. 145.

3. Pinacho R, Rita Cavero Y, Astiasarán I, Ansorena D, Calvo MI. Phenolic compounds of blackthorn (Prunus spinosa L.) and influence of in vitro digestion on their antioxidant capacity. J Funct Foods 2015;19:49-62. doi: 10.1016/j.jff.2015.09.015

4. Olszewska M, Wolbiś M. Flavonoids from the flowers of Prunus spinosa L. Acta Pol Pharm 2001;58:367-72. PMID:11876444

5. Šamec D, Durgo K, Grúz J, Kremer D, Kosalec I, PiljacŽegarac J, Salopek-Sondi B. Genetic and phytochemical variability of six Teucrium arduini L. populations and their antioxidant/prooxidant behaviour examined by biochemical, macromolecule- and cell-based approaches. Food Chem 2015;186:298-305. doi: 10.1016/j.foodchem.2014.07

6. Dorman HJD, Hiltunen R. Antioxidant and pro-oxidant in vitro evaluation of water-soluble food-related botanical extracts. Food Chem 2011;129:1612-8. doi: 10.1016/j. foodchem.2011.06.017

7. Ferlay J, Shin HR, Bray F, Forman D, Mathers C, Parkin DM. Estimates of worldwide burden of cancer in 2008: GLOBOCAN 2008. Int J Cancer 2010;127:2893-917. doi: 10.1002/ijc.25516

8. Lizcano LJ, Siles M, Trepiana J, Hernández ML, Navarro R, Ruiz-Larrea MB, Ruiz-Sanz JI. Piper and Vismia species from Colombian Amazonia differentially affect cell proliferation of hepatocarcinoma cells. Nutrients 2014;7:179-95. doi: 10.3390/ nu7010179

9. Cardellina II JH, Fuller, RW, Gamble WR, Westergaard C, Boswell J, Munro MHG, Currens M, Boyd MR. Evolving strategies for the selection, dereplication and prioritization of antitumor and HIV-inhibitory natural products extracts. In: Bohlin L, Bruhn JG, editors. Bioassaay methods in natural product research and development. Dordrecht: Kluwer Academic Publishers; 1999, p. 25-36.

10. Itharat A, Houghton PJ, Eno-Amooquaye E, Burke PJ, Sampson JH, Raman A. In vitro cytotoxic activity of Thai medicinal plants used traditionally to treat cancer. J Ethnopharmacol 2004;90:33-8. doi: 10.1016/j.jep.2003.09.014

11. Murati T, Miletić M, Štefanko A, Landeka Jurčević I, Elez Garofulić I, Dragović-Uzelac V, Kmetič I. Comparative assessment of Prunus spinosa L. flower extract in nonneoplastic hepatocytes and hepatoblastoma cells.'S Afr J Bot 2019;123:36-42. doi: 10.1016/j.sajb.2019.02.006

12. Bursać Kovačević D, Putnik P, Dragović-Uzelac V, Pedisić S, Režek Jambrak A, Herceg Z. Effects of cold atmospheric gas phase plasma on anthocyanins and color in pomegranate juice. Food Chem 2016;190:317-23. doi: 10.1016/j. foodchem.2015.05.099

13. Singleton VL, Rossi JAJ. Colorimetry of total phenolics with phosphomolybdic-phosphotungstic acid reagents. Am J Enol Vitic 1965;16:144-58.

14. Shortle E, O'Grady MN, Gilroy D, Furey A, Quinn N, Kerry JP. Influence of extraction technique on the anti-oxidative potential of hawthorn (Crataegus monogyna) extracts in bovine muscle homogenates. Meat Sci 2014;98:828-34. doi: 10.1016/j.meatsci.2014.07.001

15. Clothier RH. The FRAME cytotoxicity test (Kenacid Blue). In: O'Hare S, Atterwill CK, editors. In vitro toxicity testing protocols. Totowa (NJ): Humana Press Inc.; 1995. p. 109-18.

16. Liebsch HM, Spielmann H. Balb/c 3 T3 cytotoxicity test. In: O'Hare S, Atterwill CK, editors. In vitro toxicity testing protocols. Totowa (NJ): Humana Press Inc.; 1995. p. 177-87.

17. Kmetič I, Gaurina Srček V, Slivac I, Šimić B, Kniewald Z, Kniewald J. Atrazine exposure decreases cell proliferation in Chinese Hamster Ovary (CHO-K1) cell line. Bull Environ Contam Toxicol 2008;81:205-9. doi: 10.1007/s00128-0089425-6

18. Craciunescu O, Constantin D, Gaspar A, Toma L, Utoiu E, Moldovan L. Evaluation of antioxidant and cytoprotective activities of Arnica montana L. and Artemisia absinthium L. ethanolic extracts. Chem Cent J 2012;6:97. doi: 10.1186/1752153X-6-97

19. Murati T, Šimić B, Pleadin J, Vukmirović M, Miletić M, Durgo $\mathrm{K}$, Kniewald J, Kmetič I. Reduced cytotoxicity in PCBexposed Chinese Hamster Ovary (CHO) cells pretreated with vitamin E. Food Chem Toxicol 2017;99:17-23. doi: 10.1016/j. fct.2016.11.014

20. Han M, Li JF, Tan Q, Sun YY, Wang YY. Limitations of the use of MTT assay for screening in drug discovery. J Chinese Pharm Sci 2010;19:195-200.

21. Deng R, Hua X, Li J, Chi W, Zhang Z, Lu F, Zhang L, Pflugfelder SC, Li D-Q. Oxidative stress markers induced by hyperosmolarity in primary human corneal epithelial cells. PLoS One 2015;10:e0126561. doi: 10.1371/journal. pone. 0126561

22. Acikgoz E, Guven U, Duzagac F, Uslu R, Kara M, Soner BC, Oktem G. Enhanced G2/M arrest, caspase related apoptosis and reduced e-cadherin dependent intercellular adhesion by trabectedin in prostate cancer stem cells. PloS One 2015;10:e0141090. doi: 10.1371/journal.pone.0141090

23. Zhu $\mathrm{C}, \mathrm{Hu} \mathrm{W}, \mathrm{Wu} \mathrm{H}, \mathrm{Hu} \mathrm{X}$. No evident dose-response relationship between cellular ROS level and its cytotoxicity-a paradoxical issue in ROS-based cancer therapy. Sci Rep 2014;4:5029. doi: 10.1038/srep05029

24. Kong Q, Beel JA, Lillehei KO. A threshold concept for cancer therapy. Med Hypotheses 2000;55:29-35. doi: 10.1054/ mehy.1999.0982

25. Maurya DK, Devasagayam TP. Antioxidant and prooxidant nature of hydroxycinnamic acid derivatives ferulic and caffeic acids. Food Chem Toxicol 2010;48:3369-73. doi: 10.1016/j. fct.2010.09.006

26. León-González AJ, Auger C, Schini-Kerth VB. Pro-oxidant activity of polyphenols and its implication on cancer chemoprevention and chemotherapy. Biochem Pharmacol 2015;98:371-80. doi: 10.1016/j.bcp.2015.07.017

27. Hertzog DI, Tica, OS. Molecular mechanisms underlying the anticancerous action of flavonoids. Curr Health Sci J 2012;38:145-9.

28. Mangla B, Kohli K. Combination of natural agent with synthetic drug for the breast cancer therapy. Int J Drug Dev Res 2018;10:22-6.

29. Demain AL, Vaishnav P. Natural products for cancer chemotherapy. Microb Biotechnol 2011;4:687-99. doi: 10.1111/j.1751-7915.2010.00221.x 
Toksično djelovanje ekstrakta cvijeta Prunus spinosa L. na stanice hepatokarcinoma

Prunus spinosa L. (trnina) biljka je koja se koristi u tradicionalnoj medicini kao lijek za različite bolesti. Da bi se utvrdila njezina antikancerogena svojstva, kao model korištene su stanice humanoga hepatocelularnoga karcinoma (Hep G2) koje su izložene ekstraktu cvijeta trnine u koncentracijama $10-200 \mu \mathrm{g} / \mathrm{mL}$ te je određena citotoksična aktivnost s kenacid blue i neutral red metodama nakon 24, 48 i 72 sata inkubacije. Statistički značajni inhibitorni učinci na staničnu proliferaciju uočeni su pri koncentracijama iznad $50 \mu \mathrm{g} / \mathrm{mL}(\mathrm{p}<0,001-0,05)$. Vijabilnost stanica određena metodom neutral red bila je niža u odnosu na onu koja je određena kenacid blue metodom. Dodatno su ispitani antioksidacijski/prooksidacijski učinci ekstrakta cvijeta trnine mjerenjem reaktivnih kisikovih vrsta (ROS), a rezultati su potvrdili prooksidacijsko djelovanje u primijenjenom rasponu koncentracija. Protočnom citometrijom detektiran je visok udio stanica u apoptozi i nekrozi, što dodatno upućuje na citotoksičnost u stanicama karcinoma jetre.

KLJUČNE RIJEČI: citotoksičnost; Hep G2; kenacid blue; neutral red; ROS; trnina 